\title{
Temperature Requirements of Chrysomya albiceps (Wiedemann, 1819) (Diptera, Calliphoridae) under Laboratory Conditions
}

\author{
Margareth Maria de Carvalho Queiroz \\ Laboratório de Biologia e Controle de Insetos Vetores, Departamento de Biologia, Instituto Oswaldo Cruz, \\ Av. Brasil 4365, 21045-900 Rio de Janeiro, RJ, Brasil
}

Chrysomya albiceps specimens were obtained from colonies established with larvae and adults collected at the Federal Rural University in Rio de Janeiro, Seropédica, State of Rio de Janeiro. The larval stage of $\mathrm{C}$. albiceps was allowed to develop in climatic chambers at temperatures of 18 , 22, 27 and $32^{\circ} \mathrm{C}$, and the pupal stage was allowed to develop at 22, 27 and $32^{\circ} \mathrm{C}(60 \pm 10 \%$ RH and $14 \mathrm{hr}$ photoperiod).

The duration and viability of the larval stage of $\mathrm{C}$. albiceps at $18,22,27$ and $32^{\circ} \mathrm{C}$ were 21.30 , 10.61, 5.0 and 4.0 days and 76.5, 88.5, 98.5 and 99.5\%, respectively, with mean mature larval weights of 45.16, 81.86, 84.35 and $70.53 \mathrm{mg}$, respectively.

Mean duration and viability of the pupal stage at 22,27 and $32^{\circ} \mathrm{C}$ were $9.36,4.7$ and 3.0 days and 93.8, 100 and 100\%, respectively.

The basal temperature for the larval and pupal stage and for the larval and adult phase were 15.04, 17.39 and $15.38^{\circ} \mathrm{C}$, corresponding to 65.67, 44.15 and 114.23 DD.

Key words: blowflies - Chrysomya albiceps - temperature requirements

Chrysomya albiceps is of great medical and sanitary importance, being associated with myiasis in Africa (Zumpt 1965) and America (Guimarães et al. 1979), although it plays a more significant role as a predator of other dipteran larvae. Its potential as a vector of pathogenic microorganisms has been emphasized by several authors. The importance of this species in forensic medicine has been mentioned by Marchenko (1985). Guimarães et al. (1978) and Marchenko (1985) have pointed out the dangers of its presence in open and covered markets, garbage dumps and other biotopes because this species breeds extensively on human feces and decomposing animal tissue. According to Baumgartner and Greenberg (1984), information on the vertical distribution of Chrysomya species is limited and does not include heat tolerance ranges. According to these investigators, in Peru $C$. albiceps is a subtropical to temperate species and is rarely present at altitudes of less than $200 \mathrm{~m}\left(25.1-27^{\circ} \mathrm{C}\right)$, but abundant from 1000 to $3100 \mathrm{~m}\left(11.1-25^{\circ} \mathrm{C}\right)$, occurring up to the limit of $3325 \mathrm{~m}$. These authors showed that $C$. albiceps can tolerate night temperatures below $0^{\circ} \mathrm{C}$, as pe-

Research supported by CNPq.

Fax: +55-21-290.1146

Received 11 December 1995

Accepted 6 August 1996 riodically observed in the Andes. According to Marchenko (1985), the ideal heat range for egg laying is 25 to $27^{\circ} \mathrm{C}$.

The aim of the present study is to determine the lower temperature threshold (basal temperature) and the heat constant for different phases of the postembryonic development of $C$. albiceps, in order to contribute to the monitoring and control of this dipteran in the field and determine the most suitable conditions for its laboratory rearing.

\section{MATERIALS AND METHODS}

The specimens were obtained from C. albiceps colonies established with larvae and adults collected in the area of the W.O. Neitz Station for Parasitologic Research, Federal Rural University of Rio de Janeiro, Seropédica, State of Rio de Janeiro (22\% $45^{\prime} \mathrm{S}$ latitude, $43^{\circ} 41^{\prime} \mathrm{W}$ longitude, and $33 \mathrm{~m}$ altitude).

The larval stage of $C$. albiceps was allowed to develop in climatic chambers regulated at 18, 22, 27 and $32^{\circ} \mathrm{C}$, and the pupal stage in chambers at 22,27 and $32^{\circ} \mathrm{C}(60+10 \% \mathrm{RH}$ and $14 \mathrm{hr}$ photoperiod).

Eggs laid by the F1 generation of $C$. albiceps adults were transferred to $9.0 \times 2.0 \mathrm{~cm}$ Petri dishes lined with filter paper moistened with $1.0 \mathrm{ml}$ distilled water and maintained at $27^{\circ} \mathrm{C}$. After hatching, larvae (50 larvae/replication x 4) were placed on a diet consisting of putrefied horse meat. The methodological procedures related to the period 
from newly-hatched larva to mature larva have been described by Queiroz and Milward-deAzevedo (1991). After spontaneously leaving abandoned the diet and moved to containers with vermiculite placed below the rearing containers, the larvae were collected, individualized, weighed and then transferred to $30 \mathrm{ml}$ glass test tubes maintained under the same experimental conditions described above. The containers were filled with vermiculite to approximately $1 / 4$ of their volume and sealed with hydrophobic cotton. The observations were made daily. Due to a failure on the electric system during the developmental phase of pupae exposed to $18^{\circ} \mathrm{C}$, the data concerning this treatment were excluded from analysis. After emergence, the adults were sexed and transferred to the colonies.

To compare the effect of temperature on the biological aspects of the different phases of development, data were analyzed by the Tukey test, at the 5\% significance level.

The basal temperatures for the different periods were determined by the hyperbole method (Bean 1961). The heat constant was calculated by the formula $\mathrm{K}=\mathrm{Y}(\mathrm{t}-\mathrm{a})$ as cited by Precht et al. (1973), where $\mathrm{K}=$ heat constant (day degrees), $\mathrm{Y}=$ time of development (days), $\mathrm{t}=$ temperature at which the insect developed $\left({ }^{\circ} \mathrm{C}\right)$, and $\mathrm{a}=$ basal temperature $\left({ }^{\circ} \mathrm{C}\right)$. The results obtained by the variation of coefficient and by the graphic method discussed by Haddad and Parra (1984) were compared.

\section{RESULTS AND DISCUSSION}

The durations of the larval stage of $C$. albiceps at temperatures of $18,22,27$ and $32^{\circ} \mathrm{C}$ are presented in Table I. There was a significant difference among treatments. Larval and pupal viability were higher at 27 and $32^{\circ} \mathrm{C}$ than at $22^{\circ} \mathrm{C}$, and larval and prepupal survival rates were lowest at $18^{\circ} \mathrm{C}$ (Table I).

On the other hand, mature larvae on diets maintained at 22 and $27^{\circ} \mathrm{C}$ were much heavier than lar- vae maintained at $32^{\circ} \mathrm{C}$, their weight being about twice the mean weight of mature larvae exposed to a temperature of $18^{\circ} \mathrm{C}$ (Table II). Since the correlation between mature larval weight and the reproductive potential of insects is highly significant when no excessive weight loss occurs during pupal development, it may be inferred that temperatures below $22^{\circ} \mathrm{C}$ may be a factor related to the population growth of $C$. albiceps, although other abiotic factors may also interact with this variable. This result supports data reported by Queiroz and Carvalho (1987) who pointed out that $C$. albiceps populations significantly increase in Brazil during warmer periods of the year. The emergence rate of adults at this temperature, however, has not been considered. Queiroz and Milward-de-Azevedo (1991), working with $C$. albiceps at $27^{\circ} \mathrm{C}$, observed that the minimum weight needed for adult emergence was more than $42 \mathrm{mg}$, a value close to that reported by Levot et al. (1979) for Chrysomya rufifacies.

At $22^{\circ} \mathrm{C}$, adult emergence occurred from the 8 th to the 11th day after the diet, with females emerging from the 8th to 10th day after having, and males from the 8 th to the 11 th day (Fig. 1). At $27^{\circ} \mathrm{C}$, males and females emerged from the 4 th to the 5th day after having, with 62 and $38 \%$ of the males and 14 and $86 \%$ of the females emerging on the 4 th and 5 th day, respectively (Fig. 2). At $32^{\circ} \mathrm{C}$, $100 \%$ of the males and $98 \%$ of the females emerged on the 3rd day after having and $2 \%$ of the females emerged on the 4th day after having (Fig. 3), thus showing that, at $32^{\circ} \mathrm{C}$, adult emergence was more homogeneous.

Significant differences in the duration of pupal stage were observed at 22,27 and $32^{\circ} \mathrm{C}$ (Table I) and, even though the viability of this phase was total in the last two treatments, survival at $22^{\circ} \mathrm{C}$ was more than $90 \%$ (Table II). The statistical differences observed for this stage were similar to those observed for the egg-to-adult phase (Tables I and II).

TABLE I

Duration of the postembryonic development of second generation Chrysomya albiceps at different temperatures $(60 \pm 10 \% \mathrm{RH}$ and $14 \mathrm{hr}$ photoperiod)

\begin{tabular}{|c|c|c|c|c|c|c|c|c|c|c|c|c|}
\hline \multirow[b]{2}{*}{ Temp $\left({ }^{\circ} \mathrm{C}\right)$} & \multicolumn{3}{|c|}{$\begin{array}{l}\text { Larval stage } \\
\text { (days) }\end{array}$} & \multicolumn{3}{|c|}{$\begin{array}{l}\text { Prepupal phase } \\
\text { (days) }\end{array}$} & \multicolumn{3}{|c|}{$\begin{array}{l}\text { Pupal stage } \\
\text { (days) }\end{array}$} & \multicolumn{3}{|c|}{$\begin{array}{c}\text { Newly-hatched larva to } \\
\text { adult (days) }\end{array}$} \\
\hline & $X$ & $\pm \mathrm{s}$ & IV & $X$ & $\pm \mathrm{s}$ & IV & $X$ & $\pm s$ & IV & $X$ & $\pm s$ & IV \\
\hline 18 & 21.30 & $0.07 \mathrm{~A}$ & $18.0-24.0$ & 2.41 & $0.08 \mathrm{~A}$ & $1.0-5.0$ & & & & & & \\
\hline 22 & 10.61 & $0.04 \mathrm{~B}$ & $9.0-11.0$ & 1.85 & $0.04 \mathrm{~B}$ & $1.0-2.0$ & 9.36 & $0.10 \mathrm{~A}$ & $8.0-11.0$ & 18.08 & 0.07 & $16.0-19.0 \mathrm{~A}$ \\
\hline 27 & 5.0 & $\mathrm{C}$ & - & 1.0 & $\mathrm{C}$ & - & 4.70 & $0.06 \mathrm{~B}$ & $4.0-5.0$ & 9.34 & 0.03 & $9.0-10.0 \mathrm{~B}$ \\
\hline 32 & 4.0 & D & - & 1.0 & $\mathrm{C}$ & - & 3.0 & $0.005 \mathrm{C}$ & $3.0-0.4$ & 7.0 & 0.005 & $7.0-8.0 \mathrm{C}$ \\
\hline
\end{tabular}

Means followed by the same letter did not differ, when the Tukey tests was used. Overall significance level of $5 \%$. 
TABLE II

Prepupal weight and viability of the different phases of postembryonic development of Chrysomya albiceps at different temperatures $(60 \pm 10 \% \mathrm{RH}$ and $14 \mathrm{hr}$ photoperiod $)$

\begin{tabular}{|c|c|c|c|c|c|c|c|}
\hline $\begin{array}{l}\text { Temperature } \\
\left({ }^{\circ} \mathrm{C}\right)\end{array}$ & $\mathrm{X}$ & $\mathrm{s}$ & Range & $\begin{array}{l}\text { Larval } \\
\text { stage }\end{array}$ & $\begin{array}{l}\text { Prepupal } \\
\text { phase }\end{array}$ & $\begin{array}{l}\text { Pupal } \\
\text { stage }\end{array}$ & $\begin{array}{l}\text { Newly-hatched } \\
\text { larva to adult }\end{array}$ \\
\hline 18 & 45.16 & $1.27 \mathrm{C}$ & $18.1-64.5$ & $76.5 \mathrm{C}$ & $80.0 \mathrm{C}$ & - & - \\
\hline 22 & 81.86 & $1.23 \mathrm{~A}$ & $56.6-98.1$ & $88.5 \mathrm{~B}$ & $93.8 \mathrm{~B}$ & $93.8 \mathrm{~B}$ & $83.0 \mathrm{~B}$ \\
\hline 27 & 84.35 & $0.97 \mathrm{~A}$ & $61.3-104.7$ & $98.5 \mathrm{~A}$ & $100 \mathrm{~A}$ & $100 \mathrm{~A}$ & $98.5 \mathrm{~A}$ \\
\hline 32 & 70.53 & $1.05 \mathrm{~B}$ & $50.6-87.1$ & $99.5 \mathrm{~A}$ & $100 \mathrm{~A}$ & $100 \mathrm{~A}$ & $99.5 \mathrm{~A}$ \\
\hline
\end{tabular}

Means followed by the same letter did not differ, when the Tukey tests was used. Overall significance level of 5\%.

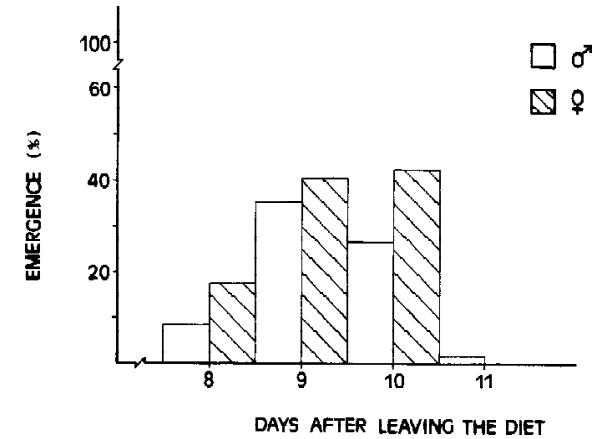

Fig. 1: emergence rhythm of second-generation males and females of Chrysomya albiceps at $22^{\circ} \mathrm{C}, 60 \pm 10 \% \mathrm{RH}$ and 14 hr photoperiod.

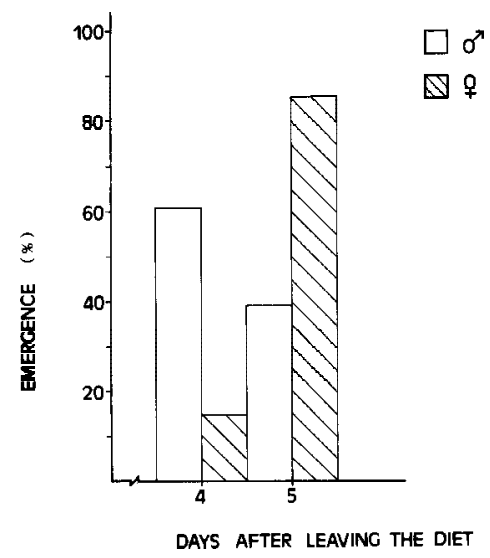

Fig. 2: emergence rhythm of second-generation males and females of Chrysomya albiceps at $27^{\circ} \mathrm{C}, 60 \pm 10 \% \mathrm{RH}$ and 14 $\mathrm{hr}$ photoperiod.

Considering the study by Marchenko (1985) which included the egg phase, was not studied in the present investigation (only the newly-hatched larva to adult were studied), a lower developmental rate was observed at $27^{\circ} \mathrm{C}(0.091)$ and $32^{\circ} \mathrm{C}$ $(0.117)$ and the highest rate was observed at $22^{\circ} \mathrm{C}$ (0.064) for the Russian strain, in contrast to the data obtained here $(0.055,0.107$ and 0.143 at 22 , 27 and $32^{\circ} \mathrm{C}$, respectively). On the other hand,

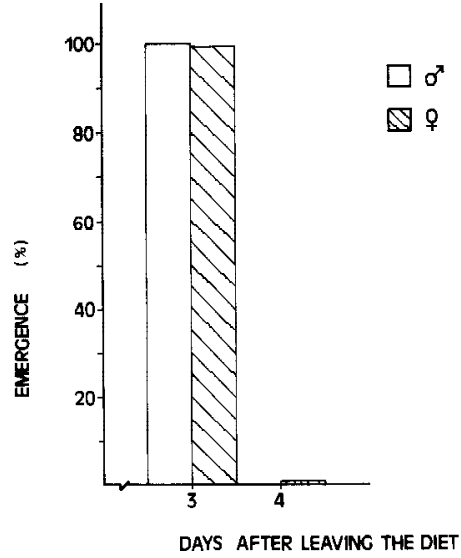

Fig. 3: emergence rhythm of second-generation males and females of Chrysomya albiceps at $32^{\circ} \mathrm{C}, 60 \pm 10 \% \mathrm{RH}$ and 14 hr photoperiod.

preliminary laboratory observations have shown that at $27^{\circ} \mathrm{C}$ the egg phase reaches a maximum of $16 \mathrm{hr}$.

Temperature requirements - The basal temperature and heat constant for the different developmental phases of $C$. albiceps obtained by the hyperbole method are presented in Table III, which also contains the data reported by Marchenko (1985). When comparing the results obtained for these variables by the hyperbole method and by the coefficient of variation, the values were found to be very close, although the hyperbole method has a better fit when it is used for at least four mean parameters (Haddad \& Parra 1984). The graphic method confirmed the results obtained for basal temperature by the previous methods.

In tropical areas of the African, Asian and American continents (Zumpt 1965, Oldroyd \& Smith 1973, Gagné 1981), C. albiceps is considered to be implicated in facultative primary myiasis. Thus, considering the responses in relation to basal temperature observed here for the larval and pupal stages $\left(=15.04\right.$ and $17.39^{\circ} \mathrm{C}$, respectively) compared to the data obtained by Marchenko (1985) for the full evolutionary cycle $\left(=10.11^{\circ} \mathrm{C}\right)$ 
TABLE III

Temperature requirements of Chrysomya albiceps reared in the laboratory $(60+10 \% \mathrm{RH}$ and $14 \mathrm{hr}$ photoperiod) (UFRRJ-RJ) and according to Marchenko (1985)

\begin{tabular}{|c|c|c|c|}
\hline $\begin{array}{l}\text { Biological } \\
\text { characteristics }\end{array}$ & $\begin{array}{c}\text { Basal } \\
\text { temperature }{ }^{a} \\
\left({ }^{\circ} \mathrm{C}\right)\end{array}$ & $\begin{array}{c}\text { Temperuture } \\
a \quad \text { constant } \\
\text { (day degree) }\end{array}$ & $\begin{array}{c}\text { Variation of } \\
\text { coeficient } \\
\left(\mathrm{r}^{2}\right)\end{array}$ \\
\hline & 15.04 & & 97.98 \\
\hline Pupal stage & 17.39 & 44.1 & 99.86 \\
\hline Larval to adult & hase 15.38 & 114.23 & 98.89 \\
\hline Egg to adult ph & $\operatorname{se}^{b} \quad 10.11$ & 186.23 & 99.99 \\
\hline
\end{tabular}

$a$ : calculated by the hyperbole method; $\mathrm{b}$ : according to Marchenko (1985)

in Russia, we may infer that this is a species currently undergoing a process of adaptation to parasitism in the tropics. The developmental rate reported by Marchenko (1985) also reveals a greater adaptation to the temperate climate by the strain studied by him compared to the strain existing in our region which, according to Guimarães et al. (1978), originates from a tropical area of the African continent (Angola). According to preliminary data, although Chrysomya megacephala has been definitely found to be adapted to the tropics (also considering its significant capacity for dispersal and colonization in the Americas where it was introduced on the same occasion as $C$. albiceps), the basal temperature presented by its immature stages is approximately $10^{\circ} \mathrm{C}$. It is also known (Coquerel), an obligatory parasite during the larval stage, develops at mean temperatures below 28 and $30^{\circ} \mathrm{C}$, although under these conditions its larvae are very small (Espin-Azeredo, pers. com.).

The difference in geographic location and/or site of origin that Cochliomyia hominivorax between the strain studied by Marchenko and ours may be the possible cause of the differences observed in the heat requirements of the species.

In a review of the literature about $C$. rufifacies, a species presenting a behavior similar to that of C. albiceps and considered by some investigators to be a subspecies of $C$. albiceps, Baumgartner (1993) reported that the temperature tolerance of this species corresponds to the distribution of the tropical region. This author also reported that at $9^{\circ} \mathrm{C}$ there is no larval hatching, at $15^{\circ} \mathrm{C}$ there is hatching but no pupation, and at $40^{\circ} \mathrm{C}$ the larvae develop normally, reaching pupation. These data are in considerable contrast to the minimum temperature for adult activity which is $13^{\circ} \mathrm{C}$ (Norris 1966, Vogt 1988 apud Baumgartner 1993).

Studies in which laboratory reared C. albiceps are exposed to temperatures above or below those used in the present experiment should be carried out to solve unclear questions. On the other hand, information about the heat requirements of an insect, evaluated from basal temperature and heat constant, permits temporary insect storage for a preestablished period of time under artificial conditions, also facilitating studies at the field level.

\section{REFERENCES}

Baumgartner DL 1993. Review of Chrysomya rufifacies (Diptera, Calliphoridae). J Med Entomol 30: 338352.

Baumgartner DL, Greenberg B 1985. Distribution medical ecology of the blow flies (Diptera, Calliphoridae) of Peru. Ann Entomol Soc Am 78: 565-587.

Bean JL 1961. Predicting emergence of second-instar spruce budworm larvae from hibernation under field conditions in Minnesota. Ann Entomol Soc Am 54: 175-177.

Gagné RJ 1981. Chrysomya spp., old world blowflies (Diptera, Calliphoridae), recently established in Americas. Bull Entomol Soc Am 27: 21-22.

Guimarães JH, Prado AP, Linhares AX 1978. Three newly introduced blowfly species in southern Brasil (Diptera, Calliphoridae). Rev Bras Entomol 22: 53-60.

Guimarães JH, Prado AP, Buralli GM 1979. Dispersal and distribuition of three newly introduced species of Chrysomya Robineau-Desvoidy in Brasil (Diptera, Calliphoridae). Rev Bras Entomol 23: 245-255.

Haddad ML, Parra JPR 1984. Métodos para estimar os limites térmicos e a faixa ótima de desenvolvimento das diferentes fases do ciclo evolutivo dos insetos. Rev Agric Desen Fundação de Estudos Agrários Luiz de Queiroz - FEALQ - Piracicaba, SP, 12pp.

Levot GW, Brown KR, Shipp E 1979. Larval growth of some Calliphorid and Sarcophagidae Diptera. Bull Entomol Res 69: 469-475.

Marchenko MI 1985. Characteristic of development of the fly Chrysomya albiceps (Wd.) (Diptera, Calliphoridae). Entomol Obozr 64: 79-84.

Norris KR 1966. Daily patterns of flight activity of blowflies (Calliphoridae: Diptera) in the Canberra district as indicated by trap catches. Aust J Zool 14: 835-853.

Oldroyd H, Smith KGV 1973. Eggs and larval of flies. In Insects and Other Arthropods of Medical Importance. Britsh Museum (Natural History), London, $561 \mathrm{pp}$.

Precht H, Christophersen J, Hensel H, Larcher W 1973. Temperature and life. New York, Heidelberg, Berlin, 779pp.

Queiroz SM, Carvalho CJB 1987. Chave pictórica e descrições de larvas de $3^{\circ}$ ínstar de Diptera (Calliphoridae, Muscidae e Fannidae) em vazadouros e resíduos sólidos domésticos em Curitiba, PR. Ann Soc Entomol Bras 16: 165-188.

Queiroz MMC, Milward-de-Azevedo EMV 1991. Técnicas de criação e alguns aspectos da Biologia de Chrysomya albiceps (Wiedemann) (Diptera, Calliphoridae), em condições de laboratório. Revta Bras Zool 8: 75-84.

Zumpt F 1965. Myiasis in man and animals in the old world. Butterworths, London, 267pp. 